\title{
On the bi-directional causal relationship between public debt and economic growth in EMU countries
}

\author{
Marta Gómez-Puig ${ }^{a^{*}}$, Simón Sosvilla-Rivero ${ }^{\mathrm{b}}$ \\ ${ }^{a}$ Department of Economic Theory, Universitat de Barcelona. 08034 Barcelona, Spain \\ ${ }^{b}$ Complutense Institute for International Studies, Universidad Complutense de Madrid. \\ 28223 Madrid, Spain \\ Revised version \\ September 2015
}

\begin{abstract}
New evidence is presented on the possible existence of bi-directional causal relationships between public debt and economic growth in both central and peripheral countries of the European Economic and Monetary Union. We test for heterogeneity in the bi-directional Granger-causality across both time and space during the period between 1980 and 2013. The results suggest evidence of a "diabolic loop" between low economic growth and high public debt levels in Spain after 2009. For Belgium, Greece, Italy and the Netherlands debt has a negative effect over growth from an endogenously determined breakpoint and above a debt threshold ranging from 56\% to $103 \%$ depending on the country.
\end{abstract}

Keywords: Public debt, economic growth, Granger-causality, euro area, peripheral EMU countries, central EMU countries.

JEL Classification Codes: C22, F33, H63, O40, O52

\footnotetext{
Corresponding author. Tel.: +34 913942342; fax: +34 913942591. E-mail addresses: marta.gomezpuig@,ub.edu (M. Gómez-Puig), sosvilla@,ccee.ucm.es (S. Sosvilla-Rivero).
} 


\section{Introduction}

Shambaugh (2012) pointed out that the European Economic and Monetary Union (EMU) countries have faced three interlocking crises (banking, sovereign debt, and economic growth) which together challenged the viability of the currency union. According to this line of thought, these crises connected with one another in several ways: the problems of weak banks and high sovereign debt were mutually reinforcing, and both were exacerbated by weak, constrained growth.

Whilst Gómez-Puig, Sosvilla-Rivero and Singh (2015) focused on the interconnection between banking and sovereign debt crises in EMU countries, in this paper we will pay attention to the interrelationship between public debt and economic growth. The empirical literature on this topic not only presents ambiguous results, but is centred mainly on the possible impact of high debt levels on economic growth, disregarding the possibility of reverse causality running from growth to debt [Ferreira (2009) and Puente-Ajovín and Sanso-Navarro (2015) are some of the few exceptions]. However, there are some theoretical reasons for thinking that public debt is likely to accumulate when growth is low (see Bell et al., 2015). In this regard, since low growth means lower government revenue, governments may be forced to increase their debt levels to maintain the welfare state, to stimulate short-term demand and to raise long-term growth (Feldstein, 2014).

Therefore, some kind of "diabolic loop" (see Brunnemeier et al., 2011) ${ }^{1}$ between high levels of debt and low levels of economic growth may have arisen with the outbreak of the financial crisis in most economies in 2008 (EMU countries among them). An increase in government debt levels both raises government deficits and changes investors' expectations. On the one hand, the rise in the government deficit increases the need to borrow and pushes up interest rates; this, through a "crowding-out" effect on private investment, may undermine economic growth. On the other, the increase in investors' risk

\footnotetext{
${ }^{1}$ These authors described the development of a "diabolic loop" between sovereign and banking risk in euro area countries.
} 
aversion may induce a "flight-to-safety" that may favour bonds of countries generally regarded to have a low default risk. In turn, as economic growth decreases, since government revenues also decline, governments are forced to increase their debt levels in order to maintain the welfare state (the economy's "automatic stabilizers" may start to work, meaning an increase in public expenditure in social security transfers, for instance). The recent European debt crisis indicates open academic questions that policy makers might need answer to. Events of the last few years have led to increasing concern about the possibly adverse consequences of the substantial accumulation of public debt of EMU countries. The debate is currently so hotly contested, because pundits draw widely different conclusions for macroeconomic policy, and in particular pro and contra economic austerity policies.

In this context, the main objective of this paper is to shed some additional light on this challenging avenue of research by applying the Granger-causality approach and endogenous breakpoint tests in order to analyse the evolution of bi-directional causality between sovereign debt and economic growth in 11 EMU countries (both central and peripheral) during a time period that spans from 1980 to 2013. Therefore, we will consider the potential heterogeneity in the bi-directional causality across both time and space (periods and countries).

Although some authors have applied the Granger methodology to examine causality between these two variables for a group of countries member of the Organization for Economic Co-operation and Development (OECD) by means of panel techniques ${ }^{2}$, to our knowledge the bi-directional causal relationship between public debt and economic growth and its evolution over time has not been examined individually for each EMU country. In particular, in order to compare our results with those of the existing literature, our paper is

2 Panizza and Presbitero (2014) also investigate causation (not correlation) between sovereign debt levels and economic growth, adopting an instrumental variable approach that captures valuation effects caused by the interaction between foreign currency debt and exchange rate volatility. 
closely related to those of Ferreira (2009) and Puente-Ajovín and Sanso-Navarro (2015) ${ }^{3}$. However, in contrast to those studies, we do not make use of panel Granger-causality tests to combine the power of cross section averaging with all the subtleties of temporal dependence; rather, we explore the time series dimension of the issue. Our methodology is data-driven and allows us to select the statistical model that best approximates the relationship between the variables under study for any particular country. We follow Ferreira (2009) regarding the need to pre-test for unit roots and cointegration (not required in the approach used by Puente-Ajovín and Sanso-Navarro, 2015), but we rely on direct estimation of individual relationships rather than on bootstrapping country-specific effects, as in Puente-Ajovín and Sanso-Navarro (2015). Moreover, our approach allows the possible Granger-causal relationships to change during the sample period (see Gómez-Puig and Sosvilla-Rivero, 2014) and to determine endogenously the breakpoints in the evolution of those relationships, thus permitting us to evaluate them before and after such breakpoints.

In our opinion, the proposed analysis is particularly relevant in an environment in which deleveraging policies need to be implemented in some euro area countries, but their beneficial effects are still a matter for debate. The rest of the paper is organized as follows. Section 2 presents a short literature review. Section 3 explains the econometric methodology, and the data and empirical results are reported in Section 4. Finally, some concluding remarks and policy implications are provided in Section 5.

\section{Literature review}

The results from the empirical literature on the relationship between public debt and economic growth are far from being conclusive (see Panizza and Presbitero (2013) for a survey). While the first studies [see, for example, Modigliani (1961), Diamond (1965) and

\footnotetext{
${ }^{3}$ Magazzino (2012) investigates the relationship between some individual items of expenditure and GDP for the Italian case using cointegration and Granger causality tests.
} 
Saint-Paul (1992)] sustained that a public debt increase always contributed to economic growth, more recent work has presented totally different results. Patillo et al., (2004) conclude that whilst low levels of public debt affect economic growth positively, high levels have a negative impact; Schclarek (2005) does not find any significant relation between public debt and economic growth in industrial countries, whereas Kumar and Woo (2010), controlling for other factors that also influence growth, detected an inverse relationship between the two variables. This long run negative relationship is also found by Mitze and Matz (2015) who study the relationship between regional public debt intensities and economic output for German federal states between 1970 and 2010.

In their seminal work, Reinhart and Rogoff (2010) studied economic growth for different thresholds of public debt using a database of 44 countries over a time period spanning 200 years. Their results suggest that the relationship is weak for public debt ratios below $90 \%$ of GDP, but that, above this threshold, on average, growth rates decrease substantially. However, since the publication of their paper, the $90 \%$ threshold has not only been questioned but has also been the focus of much of the debate in the literature: see Cecchetti et al. (2011), Minea and Paren (2012), Presbitero (2012), Baum et al. (2012), Checherita-Westphal and Rother (2012), Herdon et al. (2013) and Égert (2013), to name a few.

Moreover, the recent global recession and sovereign debt crisis in Europe have stimulated an intense debate both on the effectiveness of fiscal policies and on the consequences of public debt increases, in a situation in which leverage is already very high in European economies. In this regard,. Gómez-Puig (2013) attempts to quantify the total level of indebtedness (public and private) in all euro area countries, using a database created with the statistics provided by the European Central Bank. According to her calculations, total leverage (public and private) over GDP recorded levels of $710 \%, 487 \%, 413 \%, 360 \%$ and 353\%, in September 2012, in Ireland, Portugal, Spain, Italy and Greece respectively. 
However, it is important to stress that the main causes of the imbalances and high leverage levels in the euro area vary according to the country (see Gómez-Puig and Sosvilla-Rivero, 2013). In Ireland, the crisis was mainly due to the private sector, particularly a domestic housing boom which was financed by foreign borrowers who did not require a risk premium related to the probability of default. In Spain, since absorption exceeded production, the external debt grew and the real exchange rate appreciated, implying a loss of competitiveness for the economy. Unlike previous expansions, the resort to financing was not led by the public sector but by private households and firms. In contrast to Ireland and Spain, the origin of the debt crisis in Greece, Portugal and Italy was the structural deficit in the government sector. However, while Greek and Italian large fiscal deficit and huge public debt are the cumulative result of chronic macroeconomic imbalances, the case of Portugal illustrates the importance of external debt (specifically, that of its private sector: banks and enterprises).

In this context of low economic growth and high leverage levels in EMU countries, there is no consensus among economists about which are the right solutions to implement. While some suggest that now is precisely the time to apply the lessons learnt during the Great Depression and that policymakers should implement expansionary fiscal policies [see, among others, Krugman (2011), Berg and Ostry (2011) or DeLong and Summers (2012)] ${ }^{4}$, others argue that, since the high level of public sector leverage has a negative effect on economic growth, fiscal consolidation is fundamental to restoring confidence and improving expectations about the future evolution of the economy (Cochrane, 2011). The latter approach, which supports austerity measures, has been highly influential among the EMU authorities and has the support of the empirical evidence presented in some influential papers (Reinhart and Rogoff, 2010, among them).

\footnotetext{
4 These authors state that deleveraging policies can even prove to be detrimental, depending on the fundamental variables of the economy. Their argument currently receives support from some politicians in Southern Europe.
} 
Nevertheless, in our reading of the empirical evidence, no strong case has yet been made for a causal bi-directional relationship between public debt and economic growth in EMU countries, taking into account not only cross-country heterogeneity in the euro area, but also its time-varying nature. This paper aims to fill this gap in the literature.

\section{Econometric methodology}

\subsection{Testing for causality}

The concept of Granger-causality was introduced by Granger (1969) and Sims (1972) and is widely used to ascertain the importance of the interaction between two series. The central notion is one of predictability (Hoover, 2001): one variable Granger-causes some other variable, given an information set, if past information about the former can improve the forecast of the latter based only on its own past information. Therefore, knowledge of the evolution of one series reduces the forecast errors of the other, suggesting that the latter does not evolve independently of the former.

Testing Granger causality typically uses the same lags for all variables. This poses a potential problem, since Granger-causality tests are sensitive to lag length. Therefore, it is important that the lengths selected should be the right ones so as to avoid inconsistently estimating the model and drawing misleading inferences (see Thornton and Batten, 1985). In determining the optimal lag structure for each variable, we follow Hsiao's (1981) sequential method to test for causality, which combines Akaike (1974)'s final predictive error (FPE, from now on) and the definition of Granger-causality ${ }^{5}$. Essentially, the FPE criterion trades off the bias that arises from under-parameterization of a model against a loss in efficiency resulting from its over-parameterization, thus avoiding the ambiguities of the conventional procedure. Consider the following models:

$$
X_{\mathrm{t}}=\alpha_{0}+\sum_{i=1}^{m} \delta_{i} X_{t-i}+\varepsilon_{t}
$$

\footnotetext{
${ }^{5}$ Thornton and Batten (1985) show that Akaike (1974)'s FPE criterion performs well relative to other statistical techniques.
} 


$$
X_{t}=\alpha_{0}+\sum_{i=1}^{m} \delta_{i} X_{t-i}+\sum_{j=1}^{n} \gamma_{j} Y_{t-j}+\varepsilon_{t}
$$

where $X_{t}$ and $Y_{t}$ are stationary variables [i.e., they are $\mathrm{I}(0)$ variables]. The following steps are used to apply Hsiao's procedure for testing Granger-causality:

i) Treat $X_{t}$ as a one-dimensional autoregressive process (1), and compute its FPE with the order of lags $m$ varying from 1 to $m^{6}$. Choose the order which yields the smallest FPE, say $m$, and denote the corresponding FPE as $\mathrm{FPE}_{\mathrm{X}}(\mathrm{m}, 0)$.

ii) Treat $X_{t}$ as a controlled variable with $m$ number of lags, and treat $Y_{t}$ as a manipulated variable as in (2). Compute again the FPE of (2) by varying the order of lags of $Y_{t}$ from 1 to $n$, and determine the order which gives the smallest FPE, say $n$, and denote the corresponding FPE as $\operatorname{FPE}_{\mathrm{X}}(\mathrm{m}, \mathrm{n})^{7}$.

iii) Compare $\operatorname{FPE}_{\mathrm{X}}(\mathrm{m}, 0)$ with $\mathrm{FPE}_{\mathrm{X}}(\mathrm{m}, \mathrm{n})$ [i.e., compare the smallest FPE in step (i) with the smallest FPE in step (ii)]. If $\operatorname{FPE}_{\mathrm{X}}(\mathrm{m}, 0)>\mathrm{FPE}_{\mathrm{X}}(\mathrm{m}, \mathrm{n})$, then $Y_{t}$ is said to cause $X_{t}$. If $\mathrm{FPE}_{\mathrm{X}}(\mathrm{m}, 0)<\mathrm{FPE}_{\mathrm{X}}(\mathrm{m}, \mathrm{n})$, then $X_{t}$ is an independent process.

iv) Repeat steps i) to iii) for the $Y_{t}$ variable, treating $X_{t}$ as the manipulated variable.

When $X_{t}$ and $Y_{t}$ are not stationary variables but are first-difference stationary [i.e., they are I(1) variables] and cointegrated (see Dolado et al., 1990), it is possible to investigate the existence of a Granger-causal relationships from $\Delta X_{t}$ to $\Delta Y_{t}$ and from $\Delta Y_{t}$ to $\Delta X_{b}$, using the following error correction models:

$$
\begin{aligned}
& \Delta X_{t}=\alpha_{0}+\sum_{i=1}^{m} \delta_{i} \Delta X_{t-i}+\varepsilon_{t} \\
& \Delta X_{t}=\alpha_{0}+\beta Z_{t-1}+\sum_{i=1}^{m} \delta_{i} \Delta X_{t-i}+\sum_{j=1}^{n} \gamma_{j} \Delta Y_{t-j}+\varepsilon_{t}
\end{aligned}
$$

\footnotetext{
${ }^{6} \mathrm{FPEx}(\mathrm{m}, 0)$ is computed using the formula: $\operatorname{FPE}_{X}(m, 0)=\frac{T+m+1}{T-m-1} \cdot \frac{S S R}{T}$, where $\mathrm{T}$ is the total number of observations and SSR is the sum of squared residuals of OLS regression (1)

${ }^{7} \mathrm{FPEx}(\mathrm{m}, \mathrm{n})$ is computed using the formula: $\operatorname{FPE}_{X}(m, n)=\frac{T+m+n+1}{T-m-n-1} \cdot \frac{S S R}{T}$, where $\mathrm{T}$ is the total number of observations and SSR is the sum of squared residuals of OLS regression (2)
} 
where $Z_{t}$ is the ordinary least square (OLS) residual of the cointegrating regression $\left(X_{t}=\mu+\lambda Y_{t}\right)$, known as the error-correction term. Note that, if $X_{t}$ and $Y_{t}$ are I (1) variables, but they are not cointegrated, then $\beta$ in (4) is assumed to be equal to zero.

In both cases [i.e., $X_{t}$ and $Y_{t}$ are $\mathrm{I}(1)$ variables, and they are or are not cointegrated], we can use Hsiao's sequential procedure substituting $X_{t}$ with $\Delta X_{t}$ and $Y_{t}$ with $\Delta Y_{t}$ in steps i) to iv), as well as substituting expressions (1) and (2) with equations (3) and (4). Proceeding in this way, we ensure efficiency since the system is congruent and encompassing (Hendry and Mizon, 1999).

\subsection{Stability Diagnostics}

In conventional Granger-causality analysis, the relationship between two variables is assumed to exist at all times. However, in a time period that spans more than 30 years, parameter non-constancy may occur (with the advent of either a financial or economic crisis, or due to some other kind of shock) and may generate misleading inferences if left undetected (see Bai and Perron, 1998, 2003; Perron, 1989; Zivot and Andrews, 1992). Furthermore, the pre-testing issue in early studies may have induced a size distortion of the resulting test procedures (Bai, 1997). Thus, it is desirable to let the data select when and where regime shifts occur (i. e., we need to test for the null hypothesis of no structural change versus the alternative hypothesis that changes are present). To this end, we first identify a single structural change using the Quandt-Andrews one-time unknown structural break test. We then use the procedure suggested by Bai (1997) and Bai and Perron (1998, 2003) to detect multiple unknown breakpoints in order to obtain further evidence of the existence of the breakpoints previously detected endogenously (for a detailed description of these tests, see Gómez-Puig and Sosvilla-Rivero 2014). 


\section{Data and empirical results}

\subsection{Data}

We use annual data for the variables government debt-to-Gross Domestic Product (GDP) (denoted DEBT) and real economic growth (measured as the percentage change of GDP product at constant prices, denoted by GROWTH) from 1980 to 2013 collected from the International Monetary Fund's World Economic Outlook Database for both EMU-11 peripheral (Greece, Ireland, Italy, Portugal and Spain) and central countries (Austria, Belgium, Finland, France, Germany and the Netherlands) ${ }^{8}$.

\subsection{Preliminary results}

As a first step, we tested for the order of integration of the DEBT and GROWTH by means of the Augmented Dickey-Fuller (ADF) tests. The results decisively reject the null hypothesis of non-stationarity for DEBT but not for GROWTH, suggesting that our indicator of public debt can be treated as first-difference stationary and real growth as stationary'. Then, following Cheung and Chinn's (1997) suggestion, we confirm these results using the Kwiatkowski et al. (1992) (KPSS) tests, where the null is a stationary process against the alternative of a unit root ${ }^{10}$.

Therefore, our preliminary results indicate that, on the one hand, the relevant model for testing for Granger-causality from (percentage change in) government debt to growth is the following one:

\footnotetext{
${ }^{8}$ This distinction between central and peripheral countries has been extensively used in the empirical literature. The two groups we consider roughly correspond to the distinction made by the European Commission (1995) between those countries whose currencies continuously participated in the European Exchange Rate Mechanism (ERM) from its inception maintaining broadly stable bilateral exchange rates among themselves over the sample period, and those countries whose currencies either entered the ERM later or suspended its participation in the ERM, as well as fluctuating in value to a great extent relative to the Deutschmark. These two groups are also roughly the same found in Jacquemin and Sapir (1996), applying multivariate analysis techniques to a wide set of structural and macroeconomic indicators, to form a homogeneous group of countries. Moreover, these two groups are basically the same that those found in Ledesma-Rodríguez et al. (2005) according to the perception of economic agents with respect to the commitment to maintain the exchange rate around a central parity in the ERM and those identifying by Sosvilla-Rivero and Morales-Zumaquero (2012) using cluster analysis when analysing permanent and transitory volatilities of EMU sovereign yields.

${ }^{9}$ These results (that are not shown here in order to save space, but they are available from the authors upon request) were confirmed using Phillips-Perron (1998) unit root tests controlling for serial correlation and the Elliott, Rothenberg, and Stock (1996) Point Optimal and $\mathrm{Ng}$ and Perron (2001) unit root tests for testing non-stationarity against the alternative of high persistence. These additional results are also available from the authors.

${ }^{10}$ The results are not shown here due to space restrictions but are available from the authors upon request.
} 


$$
\begin{gathered}
\text { GROWTH } \\
t=\alpha_{0}+\sum_{i=1}^{m} \delta_{i} \text { GROWH }_{t-i}+\varepsilon_{t} \\
\mathrm{GROWTH}_{t}=\alpha_{0}+\sum_{i=1}^{m} \delta_{i} G R O W T H_{t-i}+\sum_{j=1}^{n} \gamma_{j} \Delta D E B T_{t-j}+\varepsilon_{t}
\end{gathered}
$$

where $\Delta$ denotes first difference (i. e., $\triangle D E B T_{t}=D E B T_{t}-D E B T_{t-1}$ ).

On the other hand, the relevant model for testing for Granger-causality from growth to (percentage change in) government debt is the following one ${ }^{11}$ :

$$
\begin{gathered}
\Delta D E B T_{t}=\alpha_{0}+\sum_{i=1}^{m} \delta_{i} \Delta D E B T_{t-i}+\varepsilon_{t} \\
\Delta D E B T_{t}=\alpha_{0}+\sum_{i=1}^{m} \delta_{i} \Delta D E B T_{t-i}+\sum_{j=1}^{n} \gamma_{j}{G R O W T H_{t-j}+\varepsilon_{t}}^{m}
\end{gathered}
$$

\subsection{Empirical results for the whole sample}

The resulting FPE statistics for the whole sample (1980-2013) are reported in Tables 1a and $1 \mathrm{~b} .{ }^{12}$

[Insert Tables 1 here]

Tables $1 \mathrm{a}$ and $1 \mathrm{~b}$ show that in two cases (Finland and France) our results suggest bidirectional Granger-causality; whilst in five cases (Belgium, Germany, Greece, Ireland and Portugal) we find no evidence of Granger-causality relationships in any of the directions. However, for the rest of the countries (Austria, Italy, the Netherlands and Spain) we find evidence of Granger-causality only running from the percentage change in sovereign debt to economic growth. The last column in Tables 1 reports the static long-run solution obtained from the estimated dynamic results, which can be taken as an indicator of the impact of one variable over the other (see Hendry, 1997, Chapter 7). As can be seen

\footnotetext{
11 Note that, since the variables are of different order of integration, they cannot be cointegrated and therefore there is not an error correction term in equations (5) to (8). Although the Granger representation theorem (Engle and Granger, 1987) states that if two timeseries are cointegrated, then there must be Granger causality between them (either one-way or in both directions), the converse is not true and we can still find causality between these variables.

12 These results were confirmed using both Wald statistics to test the joint hypothesis $\hat{\gamma}_{1}=\hat{\gamma}_{2}=\ldots=\hat{\gamma}_{n}=0$ in equations (6) and (8) and the Williams-Kloot test for forecasting accuracy (Williams, 1959). These additional results are not shown here in order to save space, but they are available from the authors upon request.
} 
in Table 1a, it ranges from 0.1079 to 1.2152 , suggesting a positive (and in four of the six cases very high) effect of variations in public debt on real growth; whilst Table $1 \mathrm{~b}$ displays values within the interval $(0.7107,0.8617)$, also indicating a positive and high impact of economic growth on changes in public debt-to-GDP ratios.

Summing up, when analysing the whole sample period, we find more evidence of causality running from changes in government debt to growth (we find evidence of causality in seven out of the eleven cases studied) rather than from growth to modifications in public debt (for which there is empirical evidence only in the cases of Finland and France). However, it is important to stress that in the cases where we find evidence of Grangercausality between these two variables, the effect is not negative but positive. This finding suggests that in some countries, in line with the first studies by Modigliani (1961), Diamond (1965) or Saint-Paul (1992) which contended that a public debt increase always contributed to economic growth, there is evidence of a positive effect of changes in government debt on growth, and vice-versa.

\subsection{Empirical results allowing for structural breaks}

In order to gain further insight into the dynamic Granger-causality between the percentage change in the debt-to-GDP ratio and growth, we now examine the existence of breakpoints in causality evolution in order to analyse bi-directional Granger-causality before and after the detected break dates. To do so, we do not set a specific breakpoint based on a priori knowledge about the potential break date; we first apply the Quandt-Andrews breakpoint test and let the data select when regime shifts occur in each potential causal relationship, and later we confirm the breakpoint identified by using the tests developed by Bai and Perron $(1998,2003)$ for detecting multiple structural breaks ${ }^{13}$.

The results of our tests for detecting breakpoints are presented in Tables $2 \mathrm{a}$ and $2 \mathrm{~b}^{14}$.

\footnotetext{
${ }^{13}$ We compute the breakpoint tests using a statistic which is robust to heteroskedasticity, since we estimate our original equations with Newey and West (1987) standard errors.

${ }^{14}$ In order to save space, the numerical results of Quandt-Andrews and Bai-Perron tests are not reported in Tables $2 \mathrm{a}$ and $2 \mathrm{~b}$, but are available from the authors upon request.
} 
[Insert Tables 2 here]

In particular, these tables show that in 16 out of the 22 relationships between percentage changes in public debt and growth (73\% of the total cases), the break date takes place after 2007 (coinciding with the beginning of the global financial crisis) and in more than a third of the cases $(36 \%)$ it takes place in 2009 (matching the outbreak of the European debt crisis). The exceptions are Finland, with a break date for the causal relationship that runs from growth to alterations in sovereign debt in 1995 (which might be explained by the fact that Finland joined the European Union on 1 January $1995^{15}$ ); Germany, with a break date for the causal relationship from variations in public debt to growth in 1992, and one for the relationship from growth to changes in the public debt-to-GDP ratio in 1990 (just after German reunification in 1990, which led to a boom in demand and higher inflation which the Bundesbank countered with restrictive policy measures) ${ }^{16}$; Greece with a break point in the relationship that runs from differences in government debt to economic growth in 1995 (a year identified as a turning point for the Greek economy after the Bank of Greece's adoption of the "hard drachma policy"- see, for example, Bryant et al., 2001 or Trachanas and Katrakilidis, $2013^{17}$ ); and Ireland, with a break date for the causal relationship that runs from growth to modifications in sovereign debt in 1988 (when the government debt-toGDP ratio reached its peak, with levels close to $110 \%$, before the financial crisis, in a complex economic environment with unemployment and interest rates running into double figures and emigration increasing).

Regarding the Granger-causality before and after the endogenous detected breakpoint, Table 2a shows that only in two countries (Ireland and Portugal) there was no evidence of Granger-causality between changes in public debt and growth at any point in the period,

\footnotetext{
15 The accession of Finland to the European Union took place in a difficult economic environment after the early 1990 s recession, but reinforced its tradition of fiscal responsibility. See Honkapohja and Koskela (1999) and OECD (2010).

16 On 18 May 1990, the two German states (the German Democratic Republic and the Federal Republic of Germany) signed a treaty agreeing on monetary, economic and social union. Reunification was accompanied by a massive domestic fiscal expansion as the Bonn government borrowed in order to rebuild East Germany and transfer income to its relatively poor citizens who, for their part, began to consume more and demanded higher wages.

${ }^{17}$ The aim of this policy, which meant that the exchange rate was used as a nominal anchor, was to improve the convergence of the Greek economy toward the remainder of the EU. We should recall that in 1995, the ratio of government debt-to-GDP reached levels close to $100 \%$ in Greece (see Figure 1b), far higher than those required by the Maastricht Treaty (60\%, a figure that was never fulfilled).
} 
whilst in the case of Germany, we find evidence of a positive causal relationship between variations in the debt-to-GDP ratio and growth only after the break point (1992). Nevertheless, in the eight remaining countries causality between alterations in sovereign debt and economic growth decreases after the break point. In three countries (Austria, Finland and France), the causal relationship declines but remains positive after the break date; while in the case of Belgium, Greece, Italy, the Netherlands and Spain the causal relationship between variations in public debt and growth is positive before the break but becomes negative after that date.

With respect to the causal relationship running from growth to the percentage change in the public debt-to-GDP ratio (Table $2 \mathrm{~b}$ ), we found no evidence for it in any of the periods studied for four out of the eleven countries: Austria, Greece, Italy and Portugal. In the remaining seven cases the evidence is mixed. While in three cases (Finland, Ireland and Spain) the causal relationship decreases after the break - indeed, in Finland and Spain the relationship between growth and variations in government debt is negative after the break date, suggesting that low economic growth might lead to an increase in the level of government debt - in the other four cases (Belgium, France, Germany and the Netherlands) the causal relationship between growth and the percentage change in the public debt-to-GDP ratio registers a positive increase after the break date detected in each individual country.

Tables $2 \mathrm{a}$ and $2 \mathrm{~b}$ also report the estimated static long-run solution obtained from the dynamic results (see Hendry, 1995). As can be seen in Table 2a, the static long-run parameters assessing the impact of variations of public debt on growth register a significant reduction before and after the crisis, becoming negative in four of the seven cases where we had found Granger-causality in both subperiods (ranging from -0.1063 to -0.7222 ). For Belgium and Germany, where we only detect causality after the crisis, we find a positive static long-run solution for Germany and a negative one for Belgium. Regarding Table 2b, 
for the cases of Finland and France, where we find evidence of Granger-causality before and after the crisis, while in the former case there is a sensitive reduction in the static longrun solution for the impact of growth on variations of public debt (becoming negative), in the latter case there is a forcible increase in the positive effect. Finally, for the cases where Granger-causality is only detected after the crisis, we obtain positive static long-run parameters for Belgium, Germany and the Netherlands (ranging from 0.7742 to 6.3966 ) and a high negative value for Spain (-12.3380).

Since the evidence seems much more conclusive in the relationships that run from changes in public debt to economic growth, we have plotted the evolution of the two variables, jointly with the break date in the relationship for both central and peripheral countries.

\section{[Insert Figures 1here]}

If we focus our analysis on central countries (Figure 1a), we observe that in Belgium, variations in public debt began to Granger-cause negatively economic growth from 2009 onwards when the debt-to-GDP ratio was around 96.5\%. In the Netherlands, changes in government debt began to have a negative effect on growth also from 2009 onwards, when the debt-to-GDP reached a level of $56 \%$.

In the case of peripheral countries (Figure 1b), in Greece, shifts in sovereign debt have a negative effect on growth after 1995 when the debt-to-GDP level was close to $97 \%$. In Italy, we find evidence that changes in public debt Granger-cause economic growth after 2007 when the debt-to-GDP presented a value of 103\%. Finally, in Spain, variations in government debt begin to have a negative effect on real growth after 2009 with a debt-toGDP ratio of $53 \%$.

This evidence suggests that there is a negative relationship between changes in public debt and economic growth in five of the eleven countries studied after the detected break date, and that the debt threshold above which the relationship becomes negative differs according to the country (see Table 2a). According to our evidence, this threshold ranges 
from $53 \%$ in the case of Spain to $103 \%$ in the case of Italy. These results are highly significant, since they not only reinforce the idea that causality should be examined from a dynamic point of view, but also that a specific analysis for each country is necessary, since the debt threshold above which an increase in the level of indebtedness might undermine economic performance varies according to the economic situation of each country. Moreover, three of the five cases in which we found that, after an endogenously determined break date, variations in public debt had a negative effect on growth corresponded to peripheral countries: Spain (from 2009 and a debt-threshold of 53\%), Greece (from 1995 and a debt-threshold of 97\%) and Italy (from 2009 and a debtthreshold of 103\%). Therefore, these results may have important implications for policymakers, in a context, in which they must manage the trade-off between policies that might enhance growth and those that favour a deleveraging of the economy ${ }^{18}$.

Finally, it is also noticeable that growth negatively Granger-causes percentage changes in public debt, after an endogenously determined break date, in the case of Finland and Spain (see Table 2b). In particular, in the case of Spain, we might conclude that our empirical evidence suggests the existence of a "diabolical loop" between low economic growth (the threshold rate seems to be $0.9 \%$ ) and high public debt levels after 2009, indicating that insuring against the risks of stagnation would require addressing both longer-term structural issues and crisis legacies.

\section{Concluding remarks and policy implications.}

Although the empirical literature has studied the effects of high levels of debt on economic growth, to our knowledge, no strong case has yet been made for a causal bi-directional relationship between (changes in) public debt and economic growth in EMU countries,

${ }^{18}$ Nevertheless, Aguiar et al. (2015) demonstrate that a high-debt country may be less vulnerable to crises and have higher welfare when it belongs to a union with an intermediate mix of high- and low-debt members, than one where all other members are low-debt. This contrasts with the conventional wisdom that all countries should prefer a union with low-debt members, as such a union can credibly deliver low inflation. 
taking into account not only cross-country heterogeneity in the euro area, but also its timevarying nature. The aim of this paper was to fill this gap in the literature. In order to consider the potential heterogeneity in the bi-directional causality across both time and space (periods and countries), we applied the Granger-causality approach and endogenous breakpoint tests between public debt and economic growth during the 1980-2013 period. This approach allows a deeper understanding of how the relationships between these variables might be exacerbated or mitigated during the sample.

The results for the whole sample between 1980 and 2013 are not at odds with those presented by other authors, but they do qualify them. As in our study, Panniza and Presbitero (2014) and Puente-Ajovín and Sanso-Navarro (2015) do not find negative causation (the latter examined Granger-causality) between sovereign debt and economic growth for a sample period that finishes in 2009. However, when we analyse Grangercausality after endogenously detecting a breakpoint (which, in most cases, takes place between 2007 and 2009), we find evidence of negative Granger-causality between changes in sovereign debt and growth in some of the countries studied between the break date and the end of the sample period in 2013.

As in every empirical analysis, the results must be taken with caution since they are based on a set of countries over a certain period and on a given econometric methodology. However, our findings suggest that there is evidence of a "diabolic loop" between low economic growth and high public debt levels in Spain since 2009. Moreover, in the case of Belgium, Greece, Italy and the Netherlands, variations in public debt have a negative effect over growth after an endogenously determined breakpoint and above a debt threshold that ranges from $56 \%$ to $103 \%$, depending on the country ${ }^{19}$. In addition, our findings suggest

\footnotetext{
${ }^{19}$ Although we use a completely different methodology, our results are in concordance with those presented by the authors who found that above a certain debt-to-GDP threshold an increase in public indebtedness had a negative effect on economic growth [see Reinhart and Rogoff (2010), Cecchetti et al. (2011), Minea and Paren (2012), Presbitero (2012), Baum et al. (2012), Checherita-Westphal and Rother (2012), and Égert (2013), to name a few]
} 
that considered EMU countries not only face different initial conditions, but they also have heterogeneous relations both between public debt and economic growth and between economic growth and public debt.

Taken together, our findings argue in favour of confronting the excessive fiscal imbalances in three southern EMU countries that have been hit by the recent sovereign debt crisis: Italy, Greece, and Spain, although they still register low rates of economic growth. The empirical evidence suggests that an increase in the level of public indebtedness, which might be accompanied by a relaxation of austerity programs, may not boost economic growth, but increase its decline. Nevertheless, even though we do agree that it is imperative to lower public debt over time, we also think that European policymakers need to be aware of the negative short-run effects of fiscal adjustments (see Cotarelli and Jaramillo, 2012) on growth prospects.

Therefore, we think that a right measured pace of adjustment might be preferable. Even though, this pace should differ among countries since the debt threshold above which an increase in public debt might decrease economic growth is not the same among euro area countries. In this sense, whilst the threshold is around public debt-to-GDP ratios close to $50 \%$ in Spain and the Netherlands, it clearly surpasses the $90 \%$ level in the cases of Belgium, Greece and Italy. So, in the latter countries, in particular in the Greek and Italian cases (whose economies have been severely hit by the crisis), our findings suggest that the pace of fiscal adjustment might be lower than in the former ones. Besides, in order to support growth when fiscal policy is tightened, we also support the need for reforms in goods, service, and labor markets that might improve economic efficiency and boost potential growth, serving as important tools in the fiscal adjustment process. Policies enhancing both stability and growth are possible in EMU and some of them have started being implemented while others are at an advanced stage of development. 
However, given the importance of these policy implications, we believe that further research is required to better understand and quantify the different effect of public debt on economic growth in the short and in the long run, and to guide the structural and institutional reforms needed to minimize painful economic effects for some European countries (see Anderson, Hunt and Snudden, 2014) in order to move towards the establishment of a "more perfect union"(Aizenman 2015).

\section{Acknowledgements}

This paper is based upon work supported by the Government of Spain and FEDER under grant number ECO2011-23189 and ECO2013-48326. The authors thank the insightful comments of four anonymous referees that have helped to substantially improve this paper. Marta Gómez-Puig also thanks the Instituto de Estudios Fiscales for financial support (project IEF 101/2014). Simón Sosvilla-Rivero thanks the Universitat de Barcelona \& RFA-IREA for their hospitality. Responsibility for any remaining errors rests with the authors. 


\section{References}

Aguiar, M., Amador, M., Farhi, E. and Gopinath, G. (2015) Coordination and crisis in monetary unions. Working Paper 20277, National Bureau of Economic Research, Cambridge, MA.

Aizennman, J. (2015). The Eurocrisis: muddling through, or on the way to a more perfect Euro union? Comparative Economic Studies 57: 205-221.

Akaike, H. (1974) A New Look at the Statistical Model Identification. IEEE Transactions on Automatic Control 19: 716-723.

Anderson, D., Hunt, B., and Snudden, S. (2014). Fiscal consolidation in the euro area: How much pain can structural reformsease? Journal of Policy Modeling 36, 785-799.

Andrews, D. W. K. (1993) Tests for Parameter Instability and Structural Change with Unknown Change Point. Econometrica 61: 821-856.

Andrews, D. and Ploberger, W. (1994) Optimal Tests when a Nuisance Parameter Is Present Only Under the Alternative. Econometrica 62: 1383-1414.

Bai, J. (1997) Estimating Multiple Breaks One at a Time. Econometric Theory 13: 315-352.

Bai, J. and Perron, P. (1998) Estimating and Testing Linear Models with Multiple Structural Changes. Econometrica 66: 47-78.

Bai, J. and Perron, P. (2003) Computation and Analysis of Multiple Structural Change Models. Journal of Applied Econometrics 6: 72-78.

Baum, A., Checherita-Westphal, C. and Rother, P. (2012) Debt and Growth: New Evidence for the Euro Area. Journal of International Money and Finance 32: 809-821.

Bell, A., Johnston, R. and Jones, K. (2015) Stylised Fact or Situated Messiness? The Diverse Effects of Increasing Debt on National Economic Growth. Journal of Economic Geography 15: 449-472.

Berg, A. and Ostry, J. (2011) Inequality and Unsustainable Growth: Two Sides of the Same Coin. Staff Discussion Note 11/08, International Monetary Fund, Washington DC.

Brunnermeier, M. K., Garicano, L., Lane, P. R., Pagano, M., Reis, R., Santos, T., Van Nieuwerburgh, S.and Vayanos, D. (2011) European Safe Bonds. ESBies.www.euro-nomics.com.

Bryant, R. C., Garganas, N. C., and Tavlas, G. S., (eds.) 2001. Greece's Economic Performance and Future Prospects. Bank of Greece and The Brookings Institution, Athens, Greece and Washington, D.C.

Cecchetti, S. G., Mohanty, M. and Zampolli, F. (2011) The Real Effects of Debt. Working Papers No 352, Bank for International Settlements, Basel.

Checherita-Westphal, C. and Rother, P. (2012) The Impact of High Government Debt on Economic Growth and Its Channels: An Empirical Investigation for the Euro Area. European Economic Review 56: 1392-1405.

Cheung, Y. -W. and Chinn, M. D. (1997) Further Investigation of the Uncertain Unit Root in GNP. Journal of Business and Economic Statistics 15: 68-73.

Chow, G. C. (1960). Tests of Equality between Sets of Coefficients in Two Linear Regressions. Econometrica 28: 591-605

Cochrane, J. H. (2011) Understanding Policy in the Great Recession: Some Unpleasant Fiscal Arithmetic. European Economic Review 55: 2-30.

Cotarelli, C., Jaramillo, L. (2012). Walking Hand in Hand: Fiscal Policy and Growth in Advanced Economies. Working Paper 137, International Monetary Fund, Washington DC.

Delong, B.J. and Summers, L. H. (2012) Fiscal Policy in a Depressed Economy, Brookings Papers on Economic Activity, Spring: 233-274.

Diamond, P. (1965) National Debt in a Neoclassical Growth Model. American Economic Review 55: 1126-1150.

Dolado, J. J., Jenkinson, T. and Sosvilla-Rivero, S. (1990) Cointegration and Unit Roots. Journal of Economic Surveys 4: 149-173. 
Elliott, G., Thomas J. R and, Stock, J. H. (1996) Efficient Tests for an Autoregressive Unit Root. Econometrica 64: 813-836.

Engle, R. F and, Granger, C. W. J. (1987) Co-integration and Error Correction: Representation, Estimation and Testing. Econometrica 55: 251-276.

Égert, B. (2013). The 90\% Public Debt Threshold: The Rise and Fall of a Stylised Fact. OECD Working Paper 1055, Paris.

European Commission (1995) The Impact of Exchange-rate Movements on Trade within the Single Market. European Economy 4: 1-94.

Feldstein, M. (2014). How to achieve stronger U.S. growth. Journal of Policy Modeling 36: 649-653.

Ferreira, C. (2009) Public Debt and Economic Growth: a Granger Causality Panel Data Approach. Working Paper 24, Technical University of Lisbon, Lisbon.

Gómez-Puig, M. (2013) Crisis de la Deuda Soberana y Apalancamiento en la Zona Euro: Un Intento de Cuantificación. Cuadernos de Economía: Spanish Journal of Economics and Finance 36: 67-83.

Gómez-Puig, M. and Sosvilla-Rivero, S. (2013) Granger-causality in peripheral EMU public debt markets: A dynamic approach. Journal of Banking and Finance 37: 4627-4649.

Gómez-Puig, M. and Sosvilla-Rivero, S. (2014) Causality and Contagion in EMU Sovereign Debt Markets. International Review of Economic and Finance 33: 12-27

Gómez-Puig, M., Sosvilla-Rivero, S. and Singh, M. K. (2015) Sovereigns and Banks in the Euro Area: A Tale of Two Crises. Working Papers on International Economics and Finance 15-01, Madrid.

Granger, C. W. J. (1969) Investigating Causal Relations by Econometric Models and Cross-spectral Methods. Econometrica 37: 24-36.

Hansen, B. E. (1997) Approximate Asymptotic p-values for Structural-change Tests. Journal of Business and Economic Statistics 15: 60-67.

Hendry, D. F. (1995) Dynamic Econometrics. Oxford: Oxford University Press.

Hendry, D. F. and Mizon, G. E. (1999) The Pervasiveness of Granger Causality in Econometrics. In Cointegration, Causality, and Forecasting. A Festsschrift in Honour of Clive W. J. Granger (R. F. Engle and H. White, Eds.) Oxford : Oxford University Press, pp. 102-134.

Herndon, T., Ash, M. and Pollin, R. (2013) Does High Public Debt Consistently Stifle Economic Growth? A Critique of Reinhart and Rogoff. Working Paper No. 322, Political Economy Research Institute, Amherst, MA.

Honkapohja, S. and Koskela, E. (1999) The Economic Crisis of the 1990s in Finland. Economic Policy: A European Forum 29: 399-424.

Hoover, K. D. (2001) Causality in Macroeconomics. Cambridge: Cambridge University Press.

Hsiao, C. (1981) Autoregressive Modelling and Money-income Causality Detection. Journal of Monetary Economics 7: 85-106.

Jacquemin, A. and Sapir, A. (1996) Is a European Hard Core Credible? A Statistical Analysis. Kyklos 49: 105-117.

Krugman, P. (2011) Self-defeating Austerity, New York Times, July 7.

Kumar, M. S. and Woo, J. (2010) Public Debt and Growth. Working Paper 10/174, International Monetary Fund, Washington DC.

Ledesma-Rodríguez, F., Navarro-Ibáñez, M, Pérez-Rodríguez, J. and Sosvilla-Rivero, S. (2005) Assessing the Credibility of a Target Zone: Evidence from the EMS. Applied Economics 37: 22652287.

MacKinnon, J. G. (1996) Numerical Distribution Functions for Unit Root and Cointegration Tests. Journal of Applied Econometrics 11: 601-618.

Magazzino, C. (2012). Wagner versus Keynes: Public spending and national income in Italy. Journal of Policy Modeling 34, 890-905. 
Minea, A. and Parent, A. (2012). Is High Public Debt always Harmful to Economic Growth? Reinhart and Rogoff and Some Complex Nonlinearities. Working Paper No. 8, Association Francaise de Cliometrie, Restinclières.

Mitze, T. and, Matz, F. (2015). Public debt and growth in German federal states: What can Europe learn? Journal of Policy Modeling 37: 208-228.

Newey, Whitney K. and West, K. D. (1987) A Simple, Positive Semi-Definite, Heteroskedasticity and Autocorrelation Consistent Covariance Matrix. Econometrica 55: 703-708.

Modigliani, F. (1961) Long-run Implications of Alternative Fiscal Policies and the Burden of the National Debt. Economic Journal 71: 730-755.

Ng, S. and Perron, P. (2001). Lag Length Selection and the Construction of Unit Root Tests with Good Size and Power. Econometrica 69: 1519-1554.

OECD (2010) OECD Public Governance Reviens, Finland. Organisation for Economic Co-operation and Developmen, Paris.

Panizza, H. and Presbitero, A. F. (2013) Public Debt and Economic Growth in Advanced Economies: A Survey. Swiss Journal of Economics and Statistics 149: 175-204.

Panizza, H. and Presbitero, A. F. (2014) Public Debt and Economic Growth: Is There a Causal Effect? Journal of Macroeconomics 41: 21-41.

Patillo, C., Poirson, H. and Ricci L. (2004) What Are the Channels through which External Debt Affects Growth? Working Paper 04/15, International Monetary Fund, Washington DC.

Perron, P. (1989) The Great Crash, the Oil Price Shock and the Unit Root Hypothesis. Econometrica 57: 1361-1401.

Phillips, P. C. B. and Perron, P. (1988) Testing for a Unit Root in Times Series Regression. Biometrika 75: 335-346.

Presbitero, A.F. (2012) Total Public Debt and Growth in Developing Countries. European Journal of Development Research 24: 606-626.

Puente-Ajovín, M. and Sanso-Navarro, M. (2015) Granger Causality between Debt and Growth: Evidence from OECD Countries. International Review of Economic and Finance 35: 66-77

Quandt, R. E. (1960) Tests of the Hypothesis that a Linear Regression System Obeys Two Separate Regimes. Journal of the American Statistical Association 55: 324-330.

Reinhart, C. M. and Rogoff, K. S. (2010) Growth in a Time of Debt. American Economic Review 100: 573-578.

Saint-Paul, G. (1992) Fiscal Policy in an Endogenous Growth Model. Quarterly Journal of Economics 107: 1243-1259.

Shambaugh, J. C. (2012) The Euro's Three Crises. Brookings Papers on Economic Activity 44: 157-211.

Schclarek, A. (2005) Debt and Economic Growth in Developing Industrial Countries. Working Papers No. 34. Department of Economics, Lund University, Lund.

Sims, C. A. (1972). Money, Income, and Causality. American Economic Review 62: 540-552.

Sosvilla-Rivero, S. and Morales-Zumaquero, A. (2012) Volatility in EMU Sovereign Bond Yields: Permanent and Transitory Components. Applied Financial Economics 22: 1453-1464.

Thornton, D. L., and Batten, D. S. (1985) Lag-length Selection and Tests of Granger Causality between Money and Income. Journal of Money, Credit, and Banking 27: 164-178.

Trachanas, E. and Katrakilidis, C. (2013) Fiscal Deficits under Financial Pressure and Insolvency: Evidence for Italy, Greece and Spain. Journal of Policy Modeling 35: 730-749.

Williams, E. J. (1959) Regression analysis. New York: Wiley..

Zivot, E. and Andrews, D. W. K. (1992) Further Evidence on the Great Crash, the Oil-price Shock, and the Unit-root Hypothesis. Journal of Business and Economic Statistics 10: 251-270. 
Table 1a. FPE statistics, all sample ( $\triangle$ Debt $\rightarrow$ Growth)

\begin{tabular}{|c|c|c|c|c|}
\hline & FPE(m.0) & FPE(m.n) & Causality & Impact \\
\hline$\triangle$ ATDEBT $\rightarrow$ ATGROWTH & $3.6192(1.0)$ & $3.4518(1.2)$ & Yes & 1.2152 \\
\hline$\triangle \mathrm{BEDEBT} \rightarrow \mathrm{BEGROWTH}$ & $3.4085(2.0)$ & $3.4521(2.1)$ & No & \\
\hline$\Delta$ FIDEBT $\rightarrow$ FIGROWTH & $10.5553(1.0)$ & $9.1998(1.1)$ & Yes & 0.1079 \\
\hline$\triangle$ FRDEBT $\rightarrow$ FRGROWT & $2.6149(1.0)$ & $2.2787(1.2)$ & Yes & 0.7259 \\
\hline$\Delta$ GEDEBT $\rightarrow$ GEGROWTH & $5.5113(1.0)$ & $5.6604(1.1)$ & No & \\
\hline$\Delta$ GRDEBT $\rightarrow$ GRGROWTH & $5.8721(1.0)$ & $6.2241(1.1)$ & No & \\
\hline$\Delta$ IEDEBT $\rightarrow$ IEGROWTH & $9.3414(1.0)$ & $9.7624(1.1)$ & No & \\
\hline$\Delta$ ITDEBT $\rightarrow$ ITGROWTH & $3.8557(1.0)$ & $3.3013(1.1)$ & Yes & 0.4256 \\
\hline$\Delta$ NLDEBT $\rightarrow$ NLGROWTH & $3.4411(1.0)$ & $2.8179(1.2)$ & Yes & 0.7021 \\
\hline$\Delta$ PTDEBT $\rightarrow$ PTGROWTH & $4.9873(1.0)$ & $5.3018(1.1)$ & No & \\
\hline$\triangle$ SPDEBT $\rightarrow$ SPGROWTH & $3.0333(1.0)$ & $3.0098(1.1)$ & Yes & 0.7866 \\
\hline
\end{tabular}

Table 1b. FPE statistics, all sample (Growth $\rightarrow \Delta$ Debt)

\begin{tabular}{|c|c|c|c|c|}
\hline & FPE $(\mathbf{m . 0})$ & FPE(m.n) & Causality & Impact \\
\hline ATGROWTH $\rightarrow \Delta$ ATDEBT & $8.9099(1.0)$ & $9.5225(1.1)$ & No & \\
\hline BEGROWTH $\rightarrow \Delta$ BEDEBT & $10.7905(1.0)$ & $11.3556(1.1)$ & No & $\mathbf{0 . 7 1 0 7}$ \\
\hline FIGROWTH $\rightarrow \Delta$ FIDEBT & $\mathbf{1 4 . 2 9 8 2}(\mathbf{2 . 0})$ & $\mathbf{1 3 . 9 9 9 8 ( 2 . 1 )}$ & Yes & $\mathbf{0 . 8 6 1 7}$ \\
\hline FRGROWTH $\rightarrow \Delta$ FRDEBT & $\mathbf{7 . 2 8 2 3 ( 1 . 0 )}$ & $\mathbf{7 . 0 7 4 9 ( 1 . 1 )}$ & Yes & \\
\hline GEGROWTH $\rightarrow \Delta$ GEDEBT & $4.0397(1.0)$ & $4.9406(1.1)$ & No & \\
\hline GRGROWTH $\rightarrow \Delta$ GRDEBT & $8.7370(1.0)$ & $9.2978(1.1)$ & No & \\
\hline IEGROWTH $\rightarrow \Delta$ IEDEBT & $4.3576(1.1)$ & $4.6364(1.1)$ & No & \\
\hline ITGROWTH $\rightarrow \Delta$ ITDEBT & $3.7730(1.0)$ & $4.2267(1.1)$ & No & \\
\hline NLGROWTH $\rightarrow \Delta$ NLDEBT & $4.9931(1.0)$ & $5.9658(1.1)$ & No & \\
\hline PTGROWTH $\rightarrow \Delta$ PTDEBT & $3.3260(1.0)$ & $3.7053(1.1)$ & No & \\
\hline SPGROWTH $\rightarrow \Delta$ SPDEBT & $6.8209(1.0)$ & $7.8151(1.1)$ & No & \\
\hline
\end{tabular}

Notes: The figures in brackets are the optimum order of lags in each pair of countries. Impact shows the static long-run solution. $\Delta$ denotes first difference. AT, BE, FI, FR, GE, GR, IE, IT, NL, PT and SP stand for Austria, Belgium, Finland, France, Germany, Greece, Ireland, Italy, Portugal and Spain respectively. Bold values indicate the presence of Grangercausality.

Table 2a Causality analysis by sub-periods ( $\Delta$ Debt $\rightarrow$ Growth)

\begin{tabular}{|c|c|c|c|c|}
\hline & Before the break & After the break & Break date & Debt threshold \\
\hline$\triangle$ ATDEBT $\rightarrow$ ATGROWTH & Yes (0.7086) & Yes (0.3054) & 2009 & \\
\hline$\triangle \mathrm{BEDEBT} \rightarrow \mathrm{BEGROWTH}$ & No & Yes (-0.3288) & 2009 & $97 \%$ \\
\hline$\Delta$ FIDEBT $\rightarrow$ FIGROWTH & Yes $(0.6651)$ & Yes (0.3065) & 2008 & \\
\hline$\Delta$ FRDEBT $\rightarrow$ FRGROWTH & Yes $(0.9652)$ & Yes (0.1273) & 2009 & \\
\hline$\Delta$ GEDEBT $\rightarrow$ GEGROWTH & No & Yes (0.3439) & 1992 & \\
\hline$\triangle$ GRDEBT $\rightarrow$ GRGROWTH & Yes $(0.1900)$ & Yes $(-0.7222)$ & 1995 & $97 \%$ \\
\hline$\Delta$ IEDEBT $\rightarrow$ IEGROWTH & No & No & 2008 & \\
\hline$\Delta$ ITDEBT $\rightarrow$ ITGROWTH & Yes (0.5270) & Yes (-0.1508) & 2007 & $103 \%$ \\
\hline$\triangle$ NLDEBT $\rightarrow$ NLGROWTH & Yes (2.3476) & Yes $(-0.1063)$ & 2009 & $56 \%$ \\
\hline$\triangle \mathrm{PTDEBT} \rightarrow$ PTGROWTH & No & No & 2008 & \\
\hline$\triangle$ SPDEBT $\rightarrow$ SPGROWTH & Yes (2.8895) & Yes $(-0.1074)$ & 2009 & $53 \%$ \\
\hline
\end{tabular}

Table 2b Causality analysis by sub-periods (Growth $\rightarrow \Delta$ Debt)

\begin{tabular}{|c|c|c|c|c|}
\hline & Before the break & After the break & Break date & Growth threshold \\
\hline ATGROWTH $\rightarrow \Delta$ ATDEBT & No & No & 2009 & \\
\hline BEGROWTH $\rightarrow \Delta$ BEDEBT & No & Yes (4.2152) & 2008 & 1995 \\
\hline FIGROWTH $\rightarrow \Delta$ FIDEBT & Yes (0.4863) & Yes (-0.2060) & $\mathbf{1 9 9 5}$ & \\
\hline FRGROWTH $\rightarrow \Delta$ FRDEBT & Yes (0.4127) & Yes (6.3966) & $\mathbf{2 0 0 7}$ & \\
\hline GEGROWTH $\rightarrow \Delta$ GEDEBT & No & Yes (0.7742) & 1990 & \\
\hline GRGROWTH $\rightarrow \Delta$ GRDEBT & No & No & 2009 & \\
\hline IEGROWTH $\rightarrow \Delta$ IEDEBT & Yes (3.3019) & No & 1988 & \\
\hline ITGROWTH $\rightarrow \Delta$ ITDEBT & No & No & 1995 & \\
\hline NLGROWTH $\rightarrow \Delta$ NLDEBT & No & Yes (1.4729) & 2008 & \\
\hline PTGROWTH $\rightarrow \Delta$ PTDEBT & No & No & 2009 & \\
\hline SPGROWTH $\rightarrow \Delta$ SPDEBT & No & Yes (-12.3380) & 2008 & $\mathbf{0 . 9} \%$ \\
\hline
\end{tabular}

Notes: The figures in brackets are the estimated long-run solutions. $\Delta$ denotes first difference. AT, BE, FI, FR, GE, GR, IE, IT, NL, PT and SP stand for Austria, Belgium, Finland, France, Germany, Greece, Ireland, Italy, Portugal and Spain respectively. Bold values indicate Granger-causality. Bold italic values indicate new Granger-causality not detected in the whole sample. Shaded cells indicate the detection of negative static long-run parameters after the crisis. 
Figure 1. Debt-to-GDP, Growth and breakpoint for the relationship running from $\Delta$ debt to growth: 1980-2013

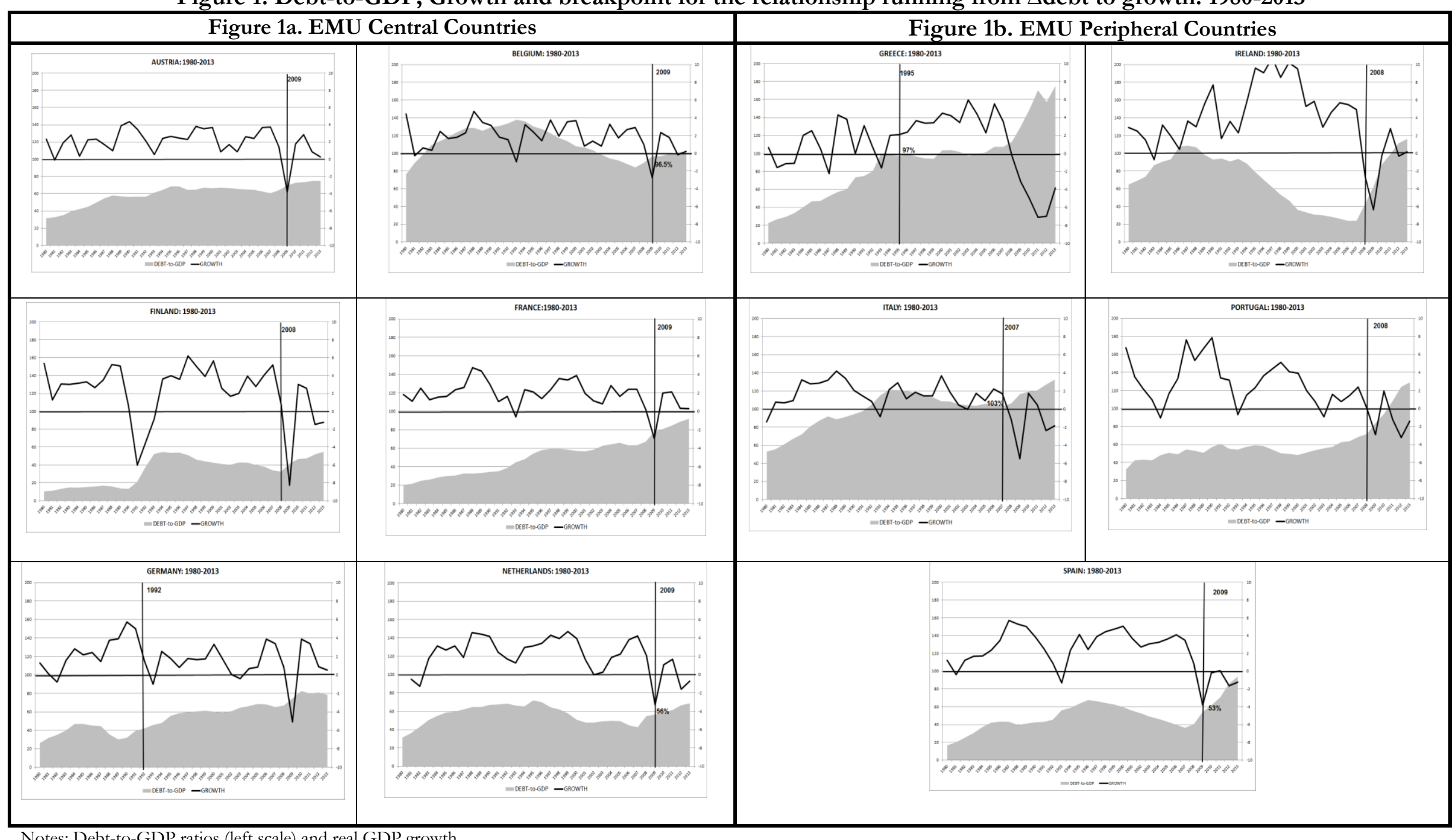

Notes: Debt-to-GDP ratios (left scale) and real GDP growth 